\title{
A ATIVIDADE NOTARIAL NO BRASIL APÓS A CONSTITUIÇÃO DE 1988
}

\author{
Thaís Grossi Andrade ${ }^{1}$ \\ Rafael Dias Medeiros ${ }^{2}$
}

RESUMO: O presente artigo objetiva analisar as mudanças na atividade notarial na ordem jurídica contemporânea após a promulgação da Constituição de 1988. Tal documento trouxe relevantes mudanças e inovações para o notariado brasileiro, precipuamente no que diz respeito às diretrizes básicas e aos princípios fundamentais da atividade. Utilizar-se-á a pesquisa bibliográfica, por meio do método dedutivo, utilizando como fonte, principalmente, revistas jurídicas, livros físicos, legislação e a jurisprudência.

Palavras-chave: Atividade. Notarial. Constituição. Mudanças. Inovações

\section{THE NOTARIAL ACTIVITY AFTER THE 1988 CONSTITUTION}

ABSTRACT: This article aimed to verify the changes in the notarial activity at the time of the promulgation of the 1988 Constitution. This law raised the changes and innovations for the Brazilian notary, precursors of the basic activity. Bibliographical research is used, through the deductive method, using as its source, mainly legal journals, physical books, legislation and jurisprudence.

Keywords: Activity. Notarial. Constitution. Changes.

\section{INTRODUÇÃO}

O obscurantismo à respeito da atividade notarial e registral possui dimensão avassaladora, até mesmo entre os estudiosos do Direito, de forma que o ramo, de grande importância, sequer é estudado nas graduações de Direito de todo o país.

A função notarial é um dos elementos fundamentais para responder às necessidades dos particulares e às solicitações do Estado observando a lei, sem a necessidade de um processo judicial.

\footnotetext{
${ }^{1}$ Advogada, com ênfase em Direito Civil, Notarial e Registral. Mestranda em Direito Privado pela Universidade FUMEC (FUMEC/MG), na linha de pesquisa "Autonomia Privada, regulação e estratégia". Especialista em Direito Notarial e Registral pela Pontifícia Universidade Católica de Minas Gerais (PUC/MG). Especialista em Direito Processual Civil pela Universidade Cândido Mendes (UCAM/RJ).

${ }^{2}$ Advogado, com ênfase em Direto do Trabalho. Professor. Mestrando em Direito Público pela Universidade FUMEC (FUMEC/MG), na linha de pesquisa "Esfera pública, legitimidade e controle". Especialista em Direito Material e Processual do Trabalho pela Universidade Cândido Mendes (UCAM/RJ).
} 
Justamente por tais motivos, o objetivo deste trabalho é proporcionar informação sobre a atividade notarial.

Embora a atuação do notário vise aplicar o direito, a fim de dar forma jurídica à vontade manifestada pelas partes e assegurar que o ato por elas almejado esteja conforme o sistema legal, é inegável que a prática notarial implique um aporte significativo ao desenvolvimento da lei.

Além de colaborar para a evolução do Direito, a função notarial é relevante e útil para a prevenção de conflitos, para a estabilização das relações contratuais, para a garantia dos direitos individuais e ainda para promover a paz social.

Nesse contexto, o eminente artigo discorrerá sobre a atividade notarial, seu histórico no Brasil e as mudanças trazidas pela promulgação da Constituição da República de 1988.

\section{DESENVOLVIMENTO}

A trajetória do notariado acompanha o desenvolvimento do direito e da sociedade ao longo dos séculos.

As pesquisas dos historiadores e os bens arqueológicos que servem de memória da vida de nossos ancestrais mostram que, desde os tempos mais remotos, a segurança era uma preocupação diuturna dos seres humanos (LOUREIRO, 2016).

Afirma-se que a segurança na vida social, com seus semelhantes, é tão importante para o indivíduo que sua consecução é o principal motivo (histórico ou sociológico) do nascimento do Direito (RECASÉNS SICHES, 1952).

Com o passar dos anos, a vida em sociedade evidenciou a imprescindibilidade de um sistema moderno de asserção e publicidade das situações jurídicas, de modo que as pessoas pudessem conhecer e planejar sua vida social e econômica com segurança e estabilidade.

Deste modo, a necessidade humana de segurança e certeza, caracterizada pela indispensabilidade de estabilidade nas relações, sejam estas jurídicas ou não, amparou esse requerimento social pelo surgimento de um agente que pudesse perpetuar no tempo os negócios privados, assegurando os direitos deles derivados (BRANDELLI, 2009).

A probabilidade de saber a verdadeira situação jurídica de pessoas e coisas caracteriza elemento indispensável à confiança no estabelecimento de relações jurídicas, o que proporciona segurança jurídica e paz social.

Por isso, a imprescindibilidade de pessoas qualificadas para solucionar os conflitos e assessorar os indivíduos na proteção de seus direitos subjetivos foi percebida e requerida nas sociedades, desde os tempos primórdios.

Observou-se, então, que o notário, ou tabelião, é uma criação social, egressa das necessidades sociais, e não uma criação das normas, o que evidencia a força, a vitalidade e a organização legal do notariado (PALOMINO, 1948). 


\subsection{Breve história do notariado brasileiro}

O primeiro tabelião a pisar em solo brasileiro foi Pero Vaz de Caminha, português, que narrou e documentou, embora sem técnica alguma, a descoberta do Brasil e a posse da terra, com todos os seus atos oficiais, traduzindo-se em único documento: a sua famosa carta à coroa portuguesa (BRANDELLI, 2009).

Como outras instituições, o notariado foi introduzido no Brasil pelos colonizadores portugueses, recebendo, portanto, grande influência do direito português.

À época da colonização, o regime legal vigente no Brasil colônia era o mesmo de Portugal, que eram as Ordenações Manuelinas e Filipinas, uma compilação dos antigos usos e costumes portugueses vigentes.

Inicialmente, as disposições normativas portuguesas da época não versavam especificamente sobre o direito notarial, ou sua função. Tratavam tão somente dos requisitos das escrituras públicas a serem observados pelos tabeliães do Reino.

Naquela época, o rei de Portugal detinha a prerrogativa exclusiva de nomear tabeliães. Com a divisão do Brasil em capitanias hereditárias, o rei cedeu aos donatários tal prerrogativa.

Tratava-se de uma classe composta por profissionais de diminuto conhecimento jurídico, que tinha a competência de formalizar a vontade das partes mediante a elaboração de instrumentos revestidos de fé pública que lhes era outorgada pelo poder real (PORTUGAL, 2018).

Assim, os primeiros tabeliães brasileiros contribuíram para a criação do direito e para a difusão da cultura jurídica. Os notários permitiam o acesso dos particulares aos bens da vida necessários para a subsistência e preveniam litígios em um território hostil e selvagem (LOUREIRO, 2016).

Posteriormente, com o insucesso das capitanias, a coroa portuguesa readquiriu os direitos conferidos aos donatários, de modo que os cargos de tabeliães eram providos por doação, adquirindo o donatário direito vitalício a eles. Existiam casos também em que a aquisição se dava por compra e venda ou mesmo por transmissão hereditária (BRANDELLI, 2009).

Com a edição no Brasil de uma lei, em 11 de outubro de 1827, os tabelionatos só poderiam ser transferidos a título de serventia vitalícia a pessoas com idoneidade moral e que servissem pessoalmente aos ofícios. Entretanto, tais pessoas não precisavam ter formação em direito.

Nesse sentido, é a lição de Contrim Neto:

A simples mudança da natureza jurídica do cargo atribuído (a passagem do regime de propriedade para o de serventia vitalícia) muito pouco influência teria no tratamento jurídico do notariado: até os anos muito recentes a venalidade (dissimulada, embora) dos ofícios da justiça, do Notariado, sobretudo, continuou; persistiu, embora do mesmo modo dissimulado, o regime da sucessão, a transmissão do cargo do pai para filho (COTRIM NETO, 1937, p. 121).

A referida lei de 1827 estabelecia, ainda, que as serventias extrajudiciais estavam sujeitas à fiscalização pelo Poder Judiciário, o que perdura até os dias atuais.

Contudo, insta salientar que por muito tempo a atividade notarial no Brasil foi utilizada como uma moeda de troca para fins políticos ou para fomentar o nepotismo. 
Com o advento do Código Civil de 1916, apenas foram disciplinados a forma jurídica e os negócios jurídicos solenes, isto é, os atos e os contratos mais relevantes nos quais deveria haver a intervenção notarial como condição de validade e eficácia (LOUREIRO, 2016).

Até certo tempo atrás, o legislador brasileiro não havia se preocupado em estabelecer um regime jurídico próprio para a classe em questão, apesar de a instituição ser muito antiga.

Assim, a inexistência de uma lei específica sobre o notariado brasileiro, especificando sua função, suas atribuições e fins, ocasionou uma repercussão negativa para a instituição, que ainda hoje, resulta em opiniões preconceituosas e pouco esclarecidas sobre o papel do tabelião e a importância de sua profissão.

Somente com a promulgação da Constituição Federal de 1988, foi instituído que os serviços notariais e de registro seriam exercidos por pessoas físicas, em caráter privado, por meio de delegação do Poder Público, através de concurso público. É o que dispõe o seu artigo 236, in verbis:

Art. 236. Os serviços notariais e de registro são exercidos em caráter privado, por delegação do Poder Público.

$\S 1^{\circ}$. Lei regulará as atividades, disciplinará a responsabilidade civil e criminal dos notários, dos oficiais de registro e seus prepostos, e definirá a fiscalização de seus atos pelo Poder Judiciário.

$\S 2^{\circ}$. Lei federal estabelecerá normas gerais para a fixação de emolumentos relativos aos atos praticados pelos serviços notariais e de registro.

$\S 3^{\circ}$. O ingresso na atividade notarial e de registro depende de concurso público de provas e títulos, não se permitindo que qualquer serventia fique vaga, sem abertura de concurso de provimento ou de remoção, por mais de seis meses. (BRASIL, 2017a)

Para regulamentar o artigo 236 da Carta Magna e seus parágrafos, foi editada a Lei $n^{\circ}$ 8.935, em 18 de novembro de 1994, também conhecida como Lei dos Cartórios, que dispõe sobre os serviços notariais e de registro.

Por se tratar de uma espécie de norma geral para as atividades notariais, a lei supracitada trouxe um reconhecimento aos notários e registradores no meio jurídico, afastando aos poucos a visão de baixo prestígio, que possuía devido à falta de aptidão para o exercício da função.

Como já mencionado, a fiscalização da função notarial é exercida pelo Poder Judiciário, que deve estabelecer as diretrizes e as normas técnicas para o exercício da função.

Para regulamentar o parágrafo segundo do artigo 236 da Constituição de 1988, foi publicada a Lei $\mathrm{n}^{0}$ 10.169, de 29 de dezembro de 2000, dispondo sobre a fixação dos emolumentos, meio pelo qual o notário é remunerado, de forma geral. 
Devido à grande extensão territorial brasileira e as particularidades de cada local, cabe aos Estados definirem os emolumentos por meio de lei estadual.

Além disso, o ingresso na função notarial ocorre por meio de concurso público, como elenca o parágrafo terceiro do artigo 236 da Constituição Federal, sendo dois terços das vagas reservadas para ingresso e um terço para remoção, destinadas aos concursados que já completaram dois anos de exercício da função.

Finalmente, esse atraso na adoção de um notariado moderno contribuiu, certamente, para a nossa ainda incipiente ciência jurídica notarial, disciplina pouco estudada e debatida na jurisprudência e na doutrina brasileira (LOUREIRO, 2016).

\subsection{A Constituição da República de 1988, a Lei no 8.935/1994 e a mudança de paradigma para a classe notarial}

A indefinição no tratamento da matéria notarial evidenciava a necessidade de uma Lei Orgânica do Notariado para regulamentar e profissionalizar a atividade, porque não é possível o desenvolvimento de uma ciência frente às constantes incertezas sobre o adequado tratamento jurídico da matéria (FILIPPO, 2009).

Com a promulgação da Constituição da República de 1988, o Estado Democrático de Direito foi inaugurado no Brasil, o que representou um importante passo para a evolução social do país e de seus cidadãos.

A Carta Magna trouxe profundas mudanças para o notariado brasileiro, sendo, portanto, considerada um divisor de águas para a classe, vez que fixou-lhe as diretrizes básicas, em seu artigo 236. O notariado brasileiro somente veio a ter um tratamento constitucional adequado, a partir da Constituição de 1988 - fato consideravelmente recente.

Posteriormente, em 18 de novembro de 1994, foi instituída a Lei no 8.935 - Lei Orgânica dos Notários e Registradores - que inaugurou uma nova fase para o notariado pátrio.

Somente o fato de ter havido o artigo 236 da Constituição Federal e a Lei $\mathrm{n}^{\circ}$ 8.935/1994, já tem o efeito arrebatador de tirar a instituição notarial do obscurantismo que a envolvia, tornando-a mais conhecida, inclusive pelos juristas, e dando notícia do seu relevo social e jurídico (BRANDELLI, 2009).

A Lei dos Cartórios e a Constituição Federal de 1988 trouxeram importantes inovações para a classe. 
Uma notória mudança versa sobre a correta designação técnica do titular da função notarial, ou seja, tabelião ou notário, definição essa trazida pela Lei $n^{\circ}$ 8.935/1994. Nesse sentindo é o ensinamento de Leonardo Brandelli:

Para que um profissional possa ser valorizado e valorizar-se é preciso, antes de mais nada, que tenha uma designação. É fato pitoresco, mas até hoje muitas pessoas não sabem quem é o titular da função notarial: chegam ao tabelionato reclamando pelo escrivão, pelo oficial, pelo oficial maior, pelo dono, mas raramente pelo tabelião ou pelo notário. O que era grave, porém, é que no mundo jurídico havia desconhecimento acerca do titular da função notarial, existindo normas que a ele se referiam como escrivão ou oficial, e neste ponto, a nova lei deu o norte correto: o profissional delegado da função notarial é o notário ou tabelião (BRANDELLI, 2009, p. 51-52).

Outrossim, a Lei $\mathrm{n}^{0}$ 8.935/1994 deixou claro que os titulares das serventias extrajudiciais não são funcionários públicos. São agentes públicos que prestam um serviço à coletividade, exercido em caráter privado por meio de delegação, sem nenhum vínculo funcional com a administração pública.

Os delegatários são particulares que, ao desempenhar funções que caberiam ao Estado, colaboram com a administração pública, sem se enquadrar na definição de funcionário público, embora não sejam ocupantes de cargo público. São agentes que exercem, em caráter de definitividade, função pública sujeita a regime especial (CARVALHO FILHO, 2008).

Contudo, dada a natureza pública dos serviços e exercendo os delegatários função pública, estão sujeitos às regras impostas ao funcionamento dos serviços públicos e são considerados funcionários públicos para efeitos penais, nos termos do artigo 327 do Código Penal, que dispõe que são considerados funcionários públicos, para efeitos penais, quem, embora transitoriamente ou sem remuneração, exerce cargo, emprego ou função pública (SOUZA, 2011).

Frisa-se, ainda, que devem ser considerados autoridades públicas para efeito de impetração de mandado de segurança, já que têm poder de decisão dentro da esfera de competência que lhes é atribuída (MEIRELLES, 1989).

Embora fiscalizados pelo Poder Judiciário, os notários possuem independência funcional. O mesmo poder é responsável também pela realização dos concursos públicos para preencher as vagas em serventias extrajudiciais de notas e registros, bem como outorgar a delegação aos aprovados naquele.

Outra novidade trazida pela Lei $n^{\circ} 8.935 / 1994$ foi a exigência do bacharelado em direito, para exercer a função de notário, além da aprovação em concurso público, item previsto no texto constitucional . 
Sobre o tema, leciona Leonardo Brandelli:

\begin{abstract}
O notário é um profissional do direito, assim como o juiz, o promotor de justiça, o advogado e o oficial do registro, por exemplo. Desempenha um mister jurídico, privativo dos que têm formação jurídica. Ao receber as partes com seus desígnios, deve o notário qualificar juridicamente sua vontade, erigindo o instrumento jurídico adequado. Essa qualificação jurídica desempenhada pelo notário é função jurídica técnica e complexa, típica dos profissionais do direito. É função relevante e profunda, que somente pode ser bem desempenhada por quem domine as ciências jurídicas. Pecou a lei, todavia, nesse sentido, ao prever uma exceção à exigência do diploma de bacharel em direito, no $\S 2^{\circ}$ do art. 15 , qual seja a de ter o candidato, até a data da primeira publicação do edital do concurso, dez anos de exercício em serventia notarial ou de registro. Não parece acertado esse dispositivo, porquanto se trata os notários e registradores de profissionais do direito, que devem ter formação acadêmica (BRANDELLI, 2009, p. 59-60).
\end{abstract}

Apesar do avanço para o reconhecimento da importância da atividade notarial para a sociedade, o texto constitucional e a sua regulamentação através da Lei $n^{\circ}$ 8.935/1994 não foi suficiente para suprir todas as deficiências e conflitos inerentes à atividade (FILIPPO, 2009).

\title{
2.3 A espécie de notariado adotada no Brasil
}

Na atualidade, existem dois principais tipos de notariado espalhados pelo globo: o latino e o anglo-saxão, que decorrem dos sistemas civil law e common law, respectivamente.

O notariado anglo-saxão, que vigora notadamente nos Estados Unidos, está inserido em uma cultura de ampla liberdade individual e máxima flexibilidade nos negócios privados, repudiando qualquer intervenção estatal, ainda que para promover a segurança jurídica (LOUREIRO, 2016).

Deste modo, o notary public - assim chamado o tabelião nesse sistema - não é um profissional do ramo do direito, é um mero legitimador de firmas, sem a função de realizar o controle de legalidade.

O modelo jurídico americano, portanto, não vela pela segurança, validade e eficácia do negócio jurídico.

Por sua vez, o notariado latino é proveniente da tradição jurídica romano-germânico, prestigiando a codificação, isto é, o direito decorre precipuamente da lei, de atos emanados do poder legislativo.

Assim, na tradição civil law, o direito foca em regras que alcancem estabilidade nas relações individuais e que previnam litígios. Tratando-se de contratos, adota a liberdade da 
forma, exceto para alguns negócios jurídicos considerados mais relevantes para a vida em sociedade que exigem uma formalidade especial.

Por isso, o notariado latino baseia-se em mecanismos como a autenticidade ou fé pública que decorrem da forma jurídica denominada documento público, característica atribuída ao notário ou tabelião, profissional oficialmente investido em sua função, que é delegada pelo Estado.

Nessa espécie de notariado, o tabelião, por meio de uma espécie de documento público, formaliza juridicamente a vontade das partes. Esse profissional é encarregado de redigir e autorizar o documento público. O documento notarial é reputado como verdadeiro em sua autoria e íntegro em seu conteúdo, além de válido e eficaz. Tal presunção de veracidade não pode ser negada pelo Estado ou por qualquer membro da coletividade, salvo por meio de impugnação judicial. (LOUREIRO, 2016).

Como se pode perceber, o Brasil adotou o notariado latino, que possui como características principais assessoramento, imparcialidade, autenticidade, conservação dos documentos, controle da legalidade e intervenção notarial. Diferentemente do notariado anglosaxão, o tabelião deve ter bacharelado em direito. No ensinamento de Adriana Abella:

O notário latino é um profissional do direito encarregado de uma função pública, que consiste em receber, interpretar e dar forma legal à vontade das partes, redigindo documentos adequados a este fim, conferindo-lhes autenticidade, conservando os originais destes e expedindo cópias que dão fé de seu conteúdo (ABELLA, 2005, p.9)

Outrossim, é a lição de Leonardo Brandelli:

O notário no Brasil é hoje um profissional do direito, assessor jurídico imparcial das
partes, que qualifica a sua vontade e redige instrumentos adequados e dotados de fé
pública; seu ingresso na atividade dá-se mediante aprovação em concurso público de
provas e títulos, após o qual lhe é delegado o exercício da atividade notarial, cabendo
a partir daí, ao Estado, fiscalização sobre tal exercício (BRANDELLI, 2009, p.94).

Assim, no Brasil, as características do sistema pretendem dar segurança às partes, esmiuçando juridicamente o contrato, antes de o tabelião proferir o devido ato notarial.

Por último, mas não menos importante, a função econômica do notariado latino é prevenir que a lide seja deflagrada, além de promover a celeridade dos negócios jurídicos relevantes de maneira segura.

\subsection{Características do notariado brasileiro}


O notariado pátrio que adota o tipo latino possui características legais que conferem ao notário a possibilidade de exercer sua função pública sob iniciativa privada.

Conforme previsto no caput do artigo 236 da Carta Magna, a atividade notarial é exercida por pessoas físicas, em caráter privado, por meio de delegação do poder público, como já se frisou alhures.

Nesse contexto, o artigo $3^{\circ}$ da Lei ${ }^{\circ}$ 8.935/1994 afirma que o tabelião e o registrador são profissionais do direito, dotados de fé pública, a quem é delegado o exercício da atividade notarial e de registro.

Por sua vez 0 art. $6^{\circ}$ da lei supracitada dispõe:

\author{
Art. $6^{\circ}$ Aos notários compete: \\ I - formalizar juridicamente a vontade das partes; \\ II - intervir nos atos e negócios jurídicos a que as partes devam ou queiram dar forma \\ legal ou autenticidade, autorizando a redação ou redigindo os instrumentos \\ adequados, conservando os originais e expedindo cópias fidedignas de seu conteúdo; \\ III - autenticar fatos.( BRASIL, 2017b)
}

Deste modo, uma importante característica da função notarial é o controle de legalidade exercido pelo tabelião nos atos e negócios jurídicos que intervém, por meio da qualificação notarial, a fim de que sejam cumpridos os requisitos necessários para que o documento notarial possa ser classificado como instrumento público.

O notário também desempenha um papel importante no que diz respeito à escolha dos meios jurídicos mais adequados para alcançar o fim almejado pelas partes.

Frisa-se que o documento público erigido pelo notário serve de prova dos fatos nele contido, decorrente da fé pública desse profissional, conforme afirma o artigo 405 do Código de Processo Civil:

Art. 405. O documento público faz prova não só da sua formação, mas também dos fatos que o escrivão, o chefe de secretaria, o tabelião ou o servidor declarar que ocorreram em sua presença.(BRASIL, 2015)

Ademais, os notários também devem intervir nos atos e negócios jurídicos a que as partes devam ou queiram dar forma legal, autorizando a redação ou redigindo os instrumentos públicos, o que torna esses profissionais responsáveis pela veracidade e eficácia desses atos. Assim, a classe possui responsabilidade subjetiva nos seus atos, conforme o disposto no artigo 22 da Lei dos Cartórios.

Assim, como assevera o artigo $1^{\circ}$ da Lei no 8.935/1994, o papel do notário é justamente garantir a publicidade, autenticidade, segurança e eficácia dos atos e negócios jurídicos. O 
tabelião também deve conservar os documentos originais e expedir cópias fidedignas (artigo $\left.6^{\circ}\right)$

A respeito da importante função dos tabeliães de intervir nos negócios jurídicos particulares, Guilherme Loureiro ensina:

\begin{abstract}
Por "autenticidade" compreende-se não apenas a certeza da autoria do instrumento contratual, mas também a fidelidade de seu conteúdo. Com efeito, a fé pública notarial abrange não apenas a veracidade da identidade, capacidade e legitimidade das partes, como também a dos fatos que ocorrem na sua presença, como as declarações manifestadas pelos contratantes. Em outras palavras, a intervenção do notário nos negócios jurídicos desejados pelos particulares garante não só a veracidade da autoria, mas também a capacidade de manifestar válida e livremente a vontade, com conhecimento de causa, e ainda a integridade do pensamento contido no documento (mas não a veracidade da substância).

Por isso, o documento notarial, que é a expressão concreta da função exercida pelo notário ou tabelião, é considerado essencial nos países de direito continental, tanto para o indivíduo quanto para o Estado. Ao primeiro, ele garante verdadeira liberdade contratual (consentimento livre com conhecimento de causa); ao segundo, ele oferece a segurança jurídica e estabilidade do regime de direito (LOUREIRO, 2016, p. 7778).
\end{abstract}

Outrossim, a conservação de documentos é outra função notória do tabelião de notas. Isso porque o instrumento público lavrado por esse profissional fica perpetuado em seu arquivo. É o que garante o artigo 6º, II, da Lei no 8.935/1994.

Outra característica relevante do notariado brasileiro é seu dever de conselho e assessoramento das partes interessadas, sempre zelando pela imparcialidade, independentemente de vir a ser lavrado o ato notarial ou não. Para tanto, deve o notário conhecer a real vontade das partes, a fim de verificar a legalidade da operação e pesquisar qual o ato ou negócio jurídico mais adequado para concretizar os objetivos dos interessados.

Como mencionado alhures, o tabelião é um profissional imparcial que possui o dever de resguardar igualmente os interesses das partes. Justamente por isso a Lei ${ }^{\circ}$ 8.935/1994, em seu artigo 28, conferiu-lhe independência funcional, como se verifica in verbis:

Art. 28. Os notários e oficiais de registro gozam de independência no exercício de suas atribuições, têm direito à percepção dos emolumentos integrais pelos atos praticados na serventia e só perderão a delegação nas hipóteses previstas em lei.( BRASIL, 2017b)

Assim sendo, o notário goza de neutralidade para exercer sua profissão, assegurada em lei. Vale lembrar, portanto, que a atividade notarial é fiscalizada pelo Poder Judiciário, embora não integre os quadros desse mesmo poder, não havendo subordinação hierárquica, como já decidido pelo Supremo Tribunal Federal anteriormente.

Há que se falar ainda da festejada característica da imediação, que se traduz na presença efetiva e pessoal do tabelião na outorga de atos e contratos. O tabelião de notas deve 
autorizar pessoalmente atos e contratos celebrados sob a forma de escritura pública. O artigo $3^{\circ}$ da Lei dos Cartórios afirma que apenas o notário é dotado de fé pública, e não os seus prepostos (LOUREIRO, 2016).

\subsection{A atividade desempenhada pelo tabelião de notas no Brasil}

Como já citado anteriormente, o notariado brasileiro adotou o tipo latino, exercendo o tabelião função pública em caráter privado, com remuneração direta pelos interessados, através do pagamento dos emolumentos.

O artigo $3^{\circ}$ da Lei $n^{0}$ 8.935/1994 afirma que os tabeliães são profissionais do direito, dotados de fé pública, a quem é delegado o exercício da atividade notarial.

De livre escolha das partes, independentemente do domicílio destas ou do lugar de situação dos bens objeto do ato ou negócio jurídico, deve o tabelião praticar atos somente dentro da base geográfica ou territorial para a qual recebeu a delegação. Assim, determinam os artigos $8^{\circ}$ e $9^{\circ}$ da Lei $n^{\circ} 8.935 / 1994$ :

Art. $8^{\circ}$ É livre a escolha do tabelião de notas, qualquer que seja o domicílio das partes ou o lugar de situação dos bens objeto do ato ou negócio.

Art. $9^{\circ} \mathrm{O}$ tabelião de notas não poderá praticar atos de seu ofício fora do Município para o qual recebeu delegação. (BRASIL, 2017b)

De acordo com o art. $6^{\circ}$ da Lei dos Cartórios, o tabelião de notas "deve formalizar juridicamente a vontade das partes, intervir nos atos e negócios jurídicos a que as partes devam ou queiram dar forma legal ou autenticidade, autorizando a redação ou redigindo os instrumentos adequados, conservando os originais e expedindo cópias fidedignas de seu conteúdo", bem como "autenticar fatos".

Ademais, compete exclusivamente aos notários lavrar escrituras públicas, procurações públicas, testamentos públicos, atas notariais, aprovar testamentos cerrados, autenticar cópias e reconhecer firmas. É o que dispõem expressamente os artigos $6^{\circ}$ e $7^{\circ}$ da Lei no 8.935/1994:

Art. $6^{\circ}$ Aos notários compete:

I - formalizar juridicamente a vontade das partes;

II - intervir nos atos e negócios jurídicos a que as partes devam ou queiram dar forma legal ou autenticidade, autorizando a redação ou redigindo os instrumentos adequados, conservando os originais e expedindo cópias fidedignas de seu conteúdo; III - autenticar fatos.

Art. $7^{\circ}$ Aos tabeliães de notas compete com exclusividade: I - lavrar escrituras e procurações, públicas; 
II - lavrar testamentos públicos e aprovar os cerrados;

III - lavrar atas notariais;

IV - reconhecer firmas;

V - autenticar cópias.

Parágrafo único. É facultado aos tabeliães de notas realizar todas as gestões e diligências necessárias ou convenientes ao preparo dos atos notariais, requerendo o que couber, sem ônus maiores que os emolumentos devidos pelo ato. (BRASIL, 2017b)

Insta consignar que os notários poderão, para o desempenho de suas funções, contratar escreventes, dentre eles escolhendo os substitutos, e auxiliares como empregados, com remuneração livremente ajustada e sob o regime da legislação do trabalho.

O número de escreventes, substitutos e auxiliares de cada tabelionato de notas é de livre escolha do tabelião, de acordo com suas necessidades.

Os escreventes poderão praticar os atos que o tabelião autorizar, e os substitutos poderão praticar todos os atos próprios da serventia, exceto lavrar testamento, de modo que as escrituras lavradas pelos escreventes devem ser por eles assinadas e encerradas pelo tabelião ou seu substituto.

Além disso, o gerenciamento administrativo e financeiro dos serviços notariais é da responsabilidade exclusiva do respectivo notário, inclusive no que diz respeito às despesas de custeio, investimento e pessoal, cabendo-lhe estabelecer normas, condições e obrigações relativas à atribuição de funções e de remuneração de seus prepostos de modo a obter a melhor qualidade na prestação dos serviços.

A respeito das escrituras públicas, não dispondo a lei em contrário, estas são essenciais à validade dos negócios jurídicos que visem à constituição, transferência, modificação ou renúncia de direitos reais sobre imóveis (artigo 108 do Código Civil), entre outras inúmeras hipóteses.

O artigo 215 do Código Civil afirma que as escrituras públicas são dotadas de fé pública e fazem prova plena, com presunção relativa de veracidade (juris tantum).

Em outra perspectiva, releva aduzir que com a edição da Lei $n^{0} 11.441$, em 4 de janeiro de 2007, passou a ser possível a realização de inventário, partilha, separação consensual e divórcio consensual por via administrativa, isto é, procedimento realizado por um tabelião de notas através de uma escritura pública.

Há que se falar também da novidade trazida pelo Código de Processo Civil de 2015 (Lei $\left.n^{\circ} 13.105 / 2015\right)$, qual seja, a usucapião extrajudicial, que deverá ter seu pedido processado diretamente perante o cartório do registro de imóveis da comarca em que estiver situado o 
imóvel usucapiendo e instruído com uma série de documentos, entre eles a ata notarial lavrada pelo tabelião, atestando o tempo de posse do requerente e de seus antecessores, conforme o caso e suas circunstâncias.

As leis $n^{0} 11.441 / 2007$ e $n^{0}$ 13.105/2015 valorizaram enormemente a profissão dos tabeliães de notas, visto que o legislador federal os reconheceu como profissionais técnicos competentes para colaborarem na solução mais célere de diversas questões importantes, sem prescindir de segurança jurídica e eficácia, representando uma evolução legislativa.

Verifica-se, portanto, que existe uma tendência atual de se afastar do Poder Judiciário conflitos que comportem outro meio de solução. A morosidade deste poder, já bastante assoberbado, e o custo do acesso à justiça incrementam as atividades que permitem aos interessados ver suas questões resolvidas sem intervenção do Poder Judiciário, que deve ser reservado para decidir conflitos em que sua atuação seja imprescindível (SOUZA, 2011).

Nesse contexto, os tabeliães de notas atuam preventivamente, evitando litígios, orientando e lavrando os instrumentos adequados, e também participando da solução de conflitos já instaurados, que admitem composição na via extrajudicial.

\subsection{A natureza jurídica da função notarial}

O artigo 236 da Constituição Federal dispõe que os serviços notariais e de registro são exercidos em caráter privado, por delegação do Poder Público.

O artigo $3^{\circ}$ da Lei $n^{\circ}$ 8.935/1994 afirma que o notário e o registrador são profissionais do direito, dotados de fé pública, a quem é delegado o exercício da atividade notarial ou de registro.

Deste modo, o exame das normas constitucionais e legais indica que o notário exerce uma função pública delegada pelo Estado, revestida de fé pública, mas como um jurista de direito privado (LOUREIRO, 2016).

Os notários são agentes públicos, mas não são funcionários públicos. São particulares em colaboração com a Administração, pessoas alheias ao aparelho estatal. Apenas para fins do direito penal, os tabeliães 4e registradores são considerados funcionários públicos em sentido amplo (LOUREIRO, 2016).

Assim, os serviços notariais e de registro são típicas atividades estatais, mas não são serviços públicos, propriamente. Categorizam-se como atividade jurídica stricto sensu, assemelhadamente às atividades jurisdicionais. E como função pública lato sensu, a exemplo 
das funções de legislação, diplomacia, defesa nacional, segurança pública, trânsito, controle externo e tantos outros cometimentos que, nem por ser de exclusivo domínio estatal, passam a se confundir com serviço público (MELLO, 2016).

Nesse sentido, foi o voto do então Ministro do Carlos Ayres Britto do Supremo Tribunal

Federal no julgamento da Ação Direta de Inconstitucionalidade $n^{\circ} 2.602$ :

(...) Temos para nós que os traços principais dos serviços notariais e de registro sejam os seguintes:

I - serviços notariais e de registro são atividades próprias do Poder Público, pela clara razão de que, se não o fossem, nenhum sentido haveria para a remissão que a Lei Maior expressamente faz ao instituto da delegação a pessoas privadas. É dizer: atividades de senhorio público, por certo, porém obrigatoriamente exercidas em caráter privado (CF, art. 236, caput). Não facultativamente, como se dá, agora sim, com a prestação dos serviços se dê por força de lei de cada pessoa federada que titularize tais serviços;

II - cuida-se de atividades jurídicas do Estado, e não de atividades simplesmente materiais, cuja prestação é traspassada para os particulares mediante delegação (já foi assinalado). Não por conduto dos mecanismos da concessão ou da permissão, normados pelo caput do art. 175 da Constituição como instrumentos contratuais de privatização do exercício dessa atividade material (não propriamente jurídica) em que se constituem os serviços públicos;

III - a delegação que lhes timbra a funcionalidade não se traduz, por nenhuma forma, em cláusulas contratuais. Ao revés, exprime-se em estatuições unilateralmente ditadas pelo Estado, valendo-se este de comandos veiculados por leis e respectivos atos regulamentares. Mais ainda, trata-se de delegação que somente pode recair sobre pessoa natural, e não sobre uma "empresa" ou pessoa mercantil, visto que de empresa ou pessoa mercantil é que versa a Magna Carta Federal em tema de concessão ou permissão de serviço público;

IV - para se tornar delegatária do Poder Público, tal pessoa natural há de ganhar habilitação em concurso público de provas e títulos. Não por adjudicação em processo licitatório, regrado pela Constituição como antecedente necessário do contrato de concessão ou de permissão para o desempenho de serviço público;

$\mathrm{V}$ - está-se a lidar com atividades estatais cujo exercício privado jaz sob a exclusiva fiscalização do Poder Judiciário, e não sob órgão ou entidade do Poder Executivo, sabido que por órgão ou entidade do Poder Executivo é que se dá a imediata fiscalização das empresas concessionárias ou permissionárias de serviços públicos. Reversamente, por órgãos do Poder Judiciário é que se marca a presença do Estado para conferir certeza e liquidez jurídica às relações inter-partes, com esta conhecida diferença: o modo usual de atuação do Poder Judiciário se dá sob o signo da contenciosidade, enquanto o invariável modo de atuação das serventias extra-forenses não adentra essa delicada esfera da litigiosidade entre sujeitos de direito; VI - enfim, as atividades notariais e de registro não se inscrevem no âmbito das remuneráveis por "tarifa" ou "preço público", mas no círculo das que se pautam por uma tabela de emolumentos, jungidos estes a normas gerais que se editam por lei necessariamente federal. Características de todo destoantes, repise-se, daquelas que são inerentes ao regime dos serviços públicos (STF, ADI 2.602, Voto do Ministro Carlos Ayres Britto. (BRASIL, 2017c, p. 96-98).

Outrossim, na Ação Direta de Inconstitucionalidade $n^{\circ}$ 2.602, o Supremo Tribunal Federal decidiu que os serviços notariais e de registros são atividades próprias do Poder Publico, que a norma constitucional delega a pessoas privadas, de forma que tais profissionais exercem uma atividade jurídica. 
Assim, tais profissionais exercem uma função pública que tem por finalidade assegurar a validade dos negócios jurídicos, a segurança jurídica e a prevenção de conflitos, caracterizando-se como auxiliares da Justiça.

\section{CONCLUSÃO}

Como exposto nesse artigo, não restam dúvidas de que a atividade exercida pelo tabelião de notas no Brasil transcende a de mero autenticador e instrumentalizador de documentos, sendo responsável por um trabalho de grande valia para a sociedade.

É importante pontuar que a função notarial é um dos elementos fundamentais para responder às necessidades dos particulares e às solicitações do Estado observando a lei, sem a necessidade de um processo judicial.

A promulgação da Constituição Federal de 1988 trouxe profundas mudanças para o notariado brasileiro, sendo, portanto, considerada um divisor de águas para a classe, uma vez que fixou-lhe as diretrizes básicas, em seu artigo 236. O notariado brasileiro somente veio a ter um tratamento constitucional adequado, a partir da atual Carta Magna - o que é um fato muito recente.

Posteriormente, em 18 de novembro de 1994, entrou em vigor a Lei $n^{\circ}$ 8.935, Lei Orgânica dos Notários e Registradores, que inaugurou uma nova fase para o notariado pátrio.

A Lei dos Cartórios e a Constituição Federal de 1988 trouxeram importantes inovações para a classe, provocando efeito arrebatador de tirar a instituição notarial do obscurantismo que a envolvia e a tornou mais conhecida, inclusive pelos juristas, dando notícia do seu relevo social e jurídico.

Conforme previsto no caput do artigo 236 da Carta Magna, a atividade notarial é exercida por pessoas físicas, em caráter privado, por meio de delegação do poder público.

De acordo com a Lei $n^{\circ}$ 8.935/1994, o tabelião e o registrador são profissionais do direito, dotados de fé pública, a quem é delegado o exercício da atividade notarial e de registro.

A despeito disso, o notariado ainda é muito desacreditado no Brasil, sobretudo em decorrência da forma como as serventias eram providas no país antes da promulgação da Constituição da República de 1988.

Como foi ressaltado neste trabalho, a função notarial consiste em uma atividade jurídico-cautelar que é deferida ao tabelião com o fim específico de dirigir imparcialmente os 
particulares na individualização de seus direitos subjetivos, para dotá-los de certeza jurídica, conforme as necessidades do tráfego e de sua prova eventual.

A importância da instituição está diretamente relacionada à paz social e à prevenção de litígios, visto que o notário formaliza a vontade das partes e lavra os respectivos instrumentos, que gozam de publicidade, autenticidade, segurança e eficácia.

Notório é que a função notarial é de extrema relevância para a sociedade contemporânea brasileira, isto porque o notário é responsável pela prestação de direção jurídica aos particulares, na esfera da espontânea realização do direito. O tabelião capta a vontade das partes e como consultor jurídico de seus clientes, assessora-lhes na busca da solução mais adequada à solução que lhe foi imposta.

Por fim, pela maneira como o notário exerce seu ofício, com impessoalidade e cautela, este previne inúmeros litígios, uma vez que atua precipuamente com o objetivo de garantir a certeza jurídica, promovendo a paz social e evita o surgimento de processos, sendo um importante cooperador da Justiça pátria.

\section{REFERÊNCIAS BIBLIOGRÁFICAS}

ABELLA, Adriana. Derecho Notarial. Derecho Documental: responsabilidad notarial. Buenos Aires: Zavalia, 2005514 p.

BRANDELLI, Leonardo. Teoria Geral do Direito Notarial. 3. ed. São Paulo: Saraiva, 2009.

BRASIL. Constituição (1988). Constituição da Republica Federativa do Brasil, Disponível em:<http://www.planalto.gov.br/ccivil_03/constituicao/constituicao.htm>. Acesso em 23 de agosto de 2017a.

BRASIL. Lei dos Cartórios (1994). Lei no 8.935/94, de 18 de novembro de 1994. Disponível em: <http://www.planalto.gov.br/ccivil_03/leis/L8935.htm>. Acesso em 28 de agosto de 2017b.

BRASIL. Supremo Tribunal Federal. Ação Direta de Inconstitucionalidade $\mathbf{n}^{\circ}$ 2.602, de 24 de novembro de 2005.2 Disponível em: $<$ http://redir.stf.jus.br/paginadorpub/paginador.jsp?docTP=AC\&docID=266859>. Acesso em 11 de setembro de 2017c.

CARVAlHO FILHO, José dos Santos. Manual de Direito Administrativo. 20 ed. Rio de Janeiro: Lumen Juris, 2008.

COTRIM NETO, Alberto; Bitencourt, Alberto. A situação jurídica do notariado brasileiro. Revista de Informação Legislativa. Brasília, n. 37, p.121, jan./mar.1973. 
FILIPPO, Filipe de. O serviço notarial à luz do artigo 236 da Constituição de 1988 e seus aspectos controvertidos. Porto Alegre: Norton Editor, 2009.

LOUREIRO, Luiz Guilherme. Manual de Direito Notarial: da atividade e dos documentos notariais. Salvador: Juspodivm, 2011.

MEIRELLES, Hely Lopes. Mandado de segurança, ação popular, ação civil pública, mandado de injunção, habeas data. 13 ed. São Paulo: Revista dos Tribunais, 1989.

MELLO, Celso Antônio Bandeira de. Curso de Direito Administrativo. 33 ed. São Paulo: Malheiros, 2016.

MOREAU, A. Le notaire dans la société française d'hier à demain. Paris: Economica, 1999.

PALOMINO, Gonzalez. Instituiciones de derecho notarial. Madrid: Reus, 1948.

PORTUGAL, Ordenações Filipinas (1603). Ordenações Filipinas, 1603. Disponível em: < http://www1.ci.uc.pt/ihti/proj/filipinas/ordenacoes.htm>. Acesso em 21 jun 2018.

RECASÉNS SICHES, Luis. Vida humana, sociedade y Derecho. 3. ed. Cidade del Mexico: Porrua, 1952.

SOUZA, Eduardo Pacheco Ribeiro de. Noções Fundamentais de Direito Registral e Notarial. São Paulo: Saraiva, 2011. 